\title{
The Effect of Dryer Type on Consumer Acceptance of Brown and Black Rice Sembada Varieties of Noodles
}

\author{
Nurdeana Cahyaningrum*, Muhammad Fajri, Siti Dewi Indrasari, and Heni Purwaningsih \\ Yogyakarta Assessment Institute for Agricultural Technology, Indonesia
}

\begin{abstract}
Noodles are foods that are liked by children, teenagers, adults, and the elderly. Noodles have become popular among the people because of their low price and simple processing and serving. Noodle processing is still made from wheat flour; people still consume more white rice, while the variety of processing noodles from brown rice flour has not been done much. The purpose of this study was to determine the effect of drying methods (cabinet dryer and sunlight) on consumer acceptance of Sembada varieties of brown rice and black rice noodles. The research method used was a completely randomized design with 3 replications. The object of research is noodles with brown rice flour substitution of $25 \%, 50 \%, 75 \%$, and $100 \%$. This research was conducted in October 2019 with a total of 30 panelists. Organoleptic test using hedonic method. The results of the organoleptic test showed that the substitution of $100 \%$ brown rice flour by drying using a cabinet dryer gave a better effect on the quality of the resulting color, which is more attractive, has a distinctive aroma and taste. brown rice flour the rice flour used, and the resulting consistency are very friendly to the panelists.
\end{abstract}

\section{Introduction}

Noodles as a noodle product from rice are quite popular among Chinese descendants and less popular in other Indonesian societies. This is thought to be related to their appearance and appearance or a different texture from wheat noodles. For example, in terms of chewiness and stickiness, where the noodles are chewier and less sticky [1]. Noodles have a shape like noodles that are clear white with a flat and wide shape and are made from rice flour, so they can be used as a substitute for rice [1]. Rice is the staple food of Indonesian society, which has a variety of shapes and colors. There are three colors of rice, namely white rice, brown rice, and black rice [2]. Rice (Oryza sp) is a food source of energy that has high carbohydrate content but low protein. The nutritional content of rice per 100 grams of material is $360 \mathrm{kcal}$ of energy, 6.6 grams of protein, 0.58 grams of fat, and 79.34 grams of carbohydrates [3]. Brown rice (Oryza Nivara) has better nutritional content than white rice, such as higher fiber content, essential fatty acids, and several vitamins than white rice.

\footnotetext{
Corresponding author: deana yk@yahoo.com
} 
The nutritional content of brown rice per $100 \mathrm{~g}$ consists of 14.6 grams of water, 7.3 grams of protein, 352 calori of energy, 0.8 grams of fiber, and 76.2 grams of carbohydrates [4].

Brown rice is rice that has many advantages over white rice, but its use in the food sector is still less than white rice. Brown rice contains many phenolic compounds ranging from simple phenolic compounds to complex compounds that bind to glucose groups as glycones. One group of phenolic compounds that have benefits as antioxidants is a group of flavonoid compounds. The group of flavonoid compounds such as anthocyanins is a group of natural ingredients in plants that act as antioxidants. Flavonoid compounds are thought to be responsible for the substances that give brown rice its color. Brown rice is rice with red color because its aleurones contain genes that are thought to produce anthocyanin compounds or other compounds that cause a red or purple color [5]

Another advantage that brown rice has is its high fiber content. The fiber in food, commonly called dietary fiber, is very good for human health. The term dietary fiber is used to distinguish dietary fiber from crude fiber, namely all polysaccharides and those that are not hydrolyzed by the work of human intestinal enzymes [5]. [6] Rice flour has a gel consistency that tends to harden after the cooking process. A tougher and denser gel consistency is produced by the high amylose in the rice, and rice with a hard gel consistency tends to be less sticky.

In Indonesia, there are many types of noodles, but the most developed is the type of noodles made from wheat flour. Indonesia is not a producer of wheat but a producer of rice and its main food is rice made from rice. Lately, wheat-based noodles have gradually shifted rice as a staple food for Indonesians. Therefore it is necessary to diversify or develop products from rice so that they are not displaced by imported foodstuffs such as wheat [1]

Diversification that can be done includes changing the raw material for white rice into brown rice which has better nutritional content in general, white rice in general so that the use of brown rice in the food sector will increase and researchers can adjust the concentration. Dry noodle quality brown rice flour. The purpose of this study was to determine the brown rice noodles and to determine the effect of the trustworthiness of brown rice flour on consumer acceptance and nutritional composition based on the results of the best consumer acceptance.

\section{Materials and Methods}

\subsection{Time and place of research}

The research was conducted at the Yogyakarta AIAT Postharvest Laboratory in AugustSeptember 2019.

\subsection{Materials and tools}

The materials used in this study were: brown rice, wheat flour, salt, sodium triple phosphate, eggs, and cooking oil. The equipment used in this study were: measuring cups, scales, pans, basins, ovens, noodle makers. 


\subsection{Research stages}

The first stage is the manufacture of flour and noodles for brown rice and black rice. Processing noodles brown and black rice noodles with concentrations of $25 \%, 50 \%, 75 \%$, and $100 \%$ with different types of dryers, namely sun drying and cabinet dryers.

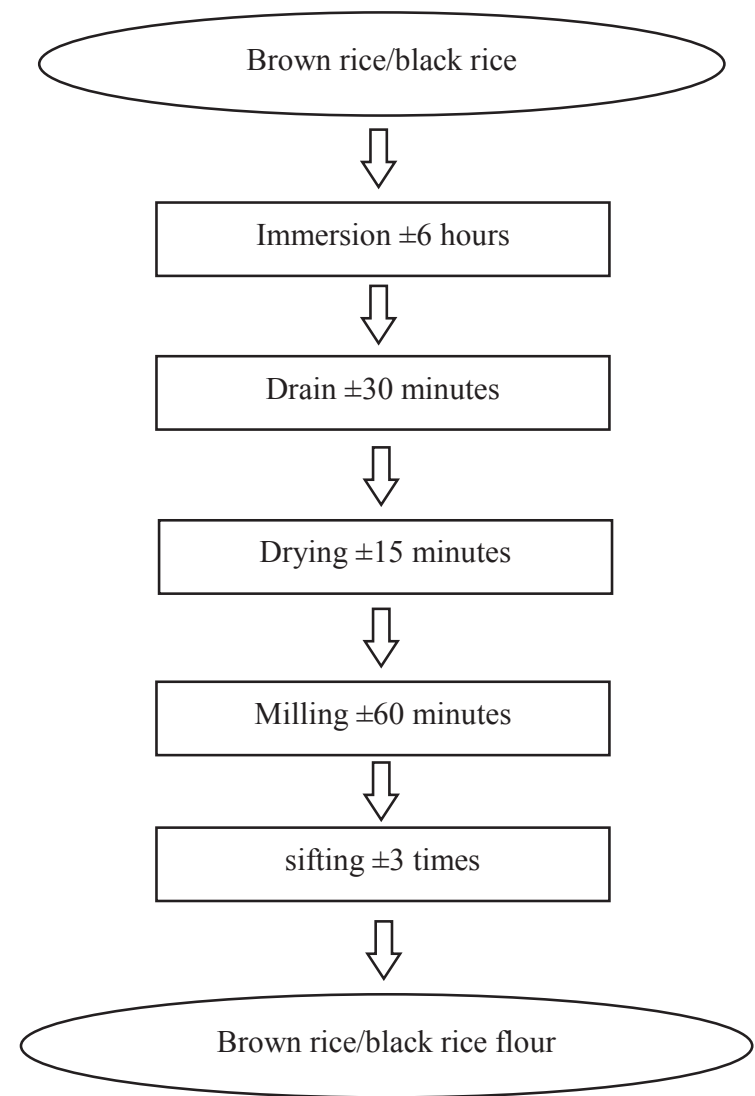

Fig 1. The process of making rice flour 


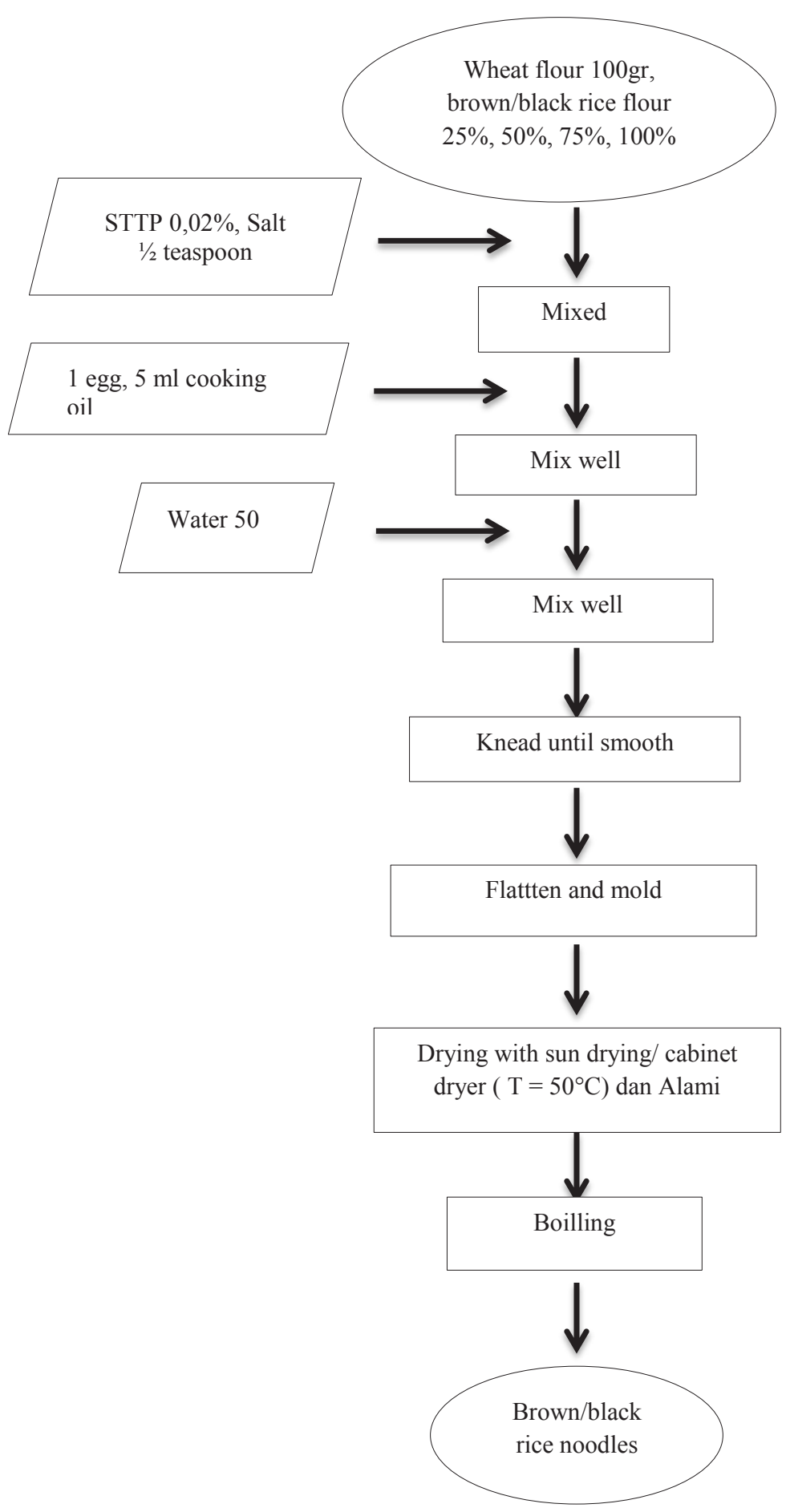

Fig. 2. The stage of making brown/black rice noodles 


\subsection{Organoleptic Test}

Organoleptic test has been carried out to determine consumer preferences for brown rice noodles and black rice various concentrations of addition $25 \%$ (A1, B1), 50\% (A2,B2), $75 \%(\mathrm{~A} 3, \mathrm{~B} 3)$ and $100 \%(\mathrm{~A} 4, \mathrm{~B} 4)$

\subsection{Chemical Analysis}

Based on the results of the organoleptic test most preferred by consumers, it is continued with the analysis of nutritional components including fat, protein, calcium, and carbohydrates.

\section{Results and Discussion}

\subsection{Color}

Color is a visual character that can be assessed with the eye so that serving less attractive food will reduce consumer interest [7]. Based on the results of the data shows that the treatment of rice type and concentration, as well as the drying method, has a significant effect on the color of the noodles (Table 1 and Figure 3). The color of black rice noodles is thicker than brown rice, which tends to be pink in color. After boiling, the color intensity of the noodles is reduced. This is because brown rice and black rice contain water-soluble anthocyanins. [8] the color of the boiled noodles turns pale, this is because the wet noodles when boiled are decomposed by water so that the color changes and is also influenced by the content of the flour used in the manufacturing process.

Based on the ANOVA test at a significant difference of 5\% and $1 \%$ indicated that the panelists preferred noodles with $100 \%$ brown rice. The color of the noodles is more attractive compared to the greater concentration of other brown rice.

Table 1. The results of the consumer preference for the color of the noodles

\begin{tabular}{|c|c|c|c|c|c|c|}
\hline \multirow{2}{*}{$\mathrm{Sk}$} & $\mathrm{db}$ & \multirow{2}{*}{$\mathrm{Jk}$} & \multirow{2}{*}{$\mathrm{Kt}$} & \multirow{2}{*}{ F Count } & \multicolumn{2}{|c|}{$\mathrm{F} \mathrm{Table}$} \\
\cline { 6 - 7 } & & & & & $5 \%$ & $1 \%$ \\
\hline Sample & 15 & 16.46 & 1.10 & 1.09 & 1.71 & 2.13 \\
\hline Panelists & 14 & 80.18 & 5.73 & & & \\
\hline Error & 210 & 212.35 & 1.01 & & & \\
\hline Total & 239 & 308.996 & & & & \\
\hline
\end{tabular}

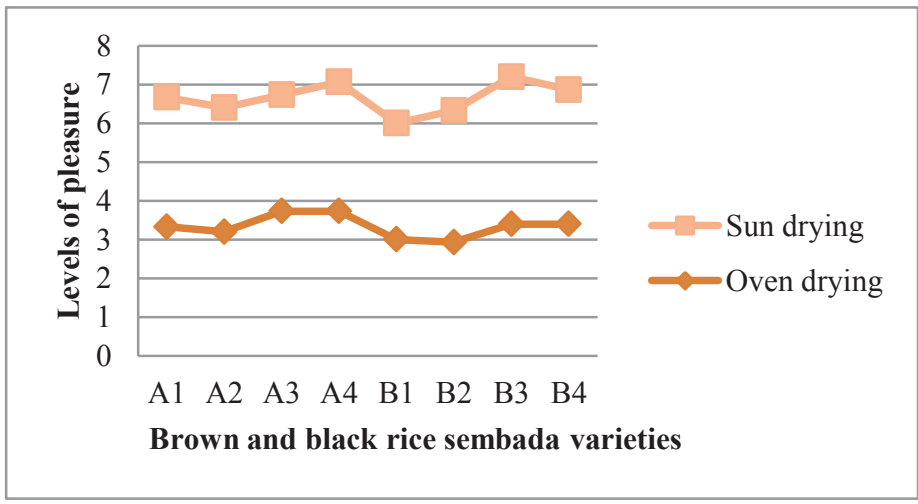

Fig. 3. Consumer preferences for the color of noodles 


\subsection{Aroma}

Results of statistical analysis on the preference test for the aroma of noodles showed that there was a significant difference at the 5\% significance level of the aroma of brown rice noodles and black rice. Panelists prefer oven-dried noodles. The preferences of the panelists are shown in Table 2 and Figure 4.

Table 2. The results of the ANOVA test of consumer preferences for the aroma of noodles

\begin{tabular}{|c|c|c|c|c|c|c|}
\hline \multirow{2}{*}{$\mathrm{Sk}$} & $\mathrm{db}$ & \multirow{2}{*}{$\mathrm{Jk}$} & \multirow{2}{*}{$\mathrm{Kt}$} & \multirow{2}{*}{$\mathrm{F}$ Count } & \multicolumn{2}{|c|}{$\mathrm{F} \mathrm{Table}$} \\
\cline { 6 - 8 } & & & & & $5 \%$ & $1 \%$ \\
\hline Samples & 15 & 5.47 & 0.37 & 0.39 & 1.71 & 2.13 \\
\hline Panelists & 14 & 26.74 & 1.91 & & & \\
\hline Error & 210 & 198.59 & 0.95 & & & \\
\hline Total & 239 & 230.8 & & & & \\
\hline
\end{tabular}

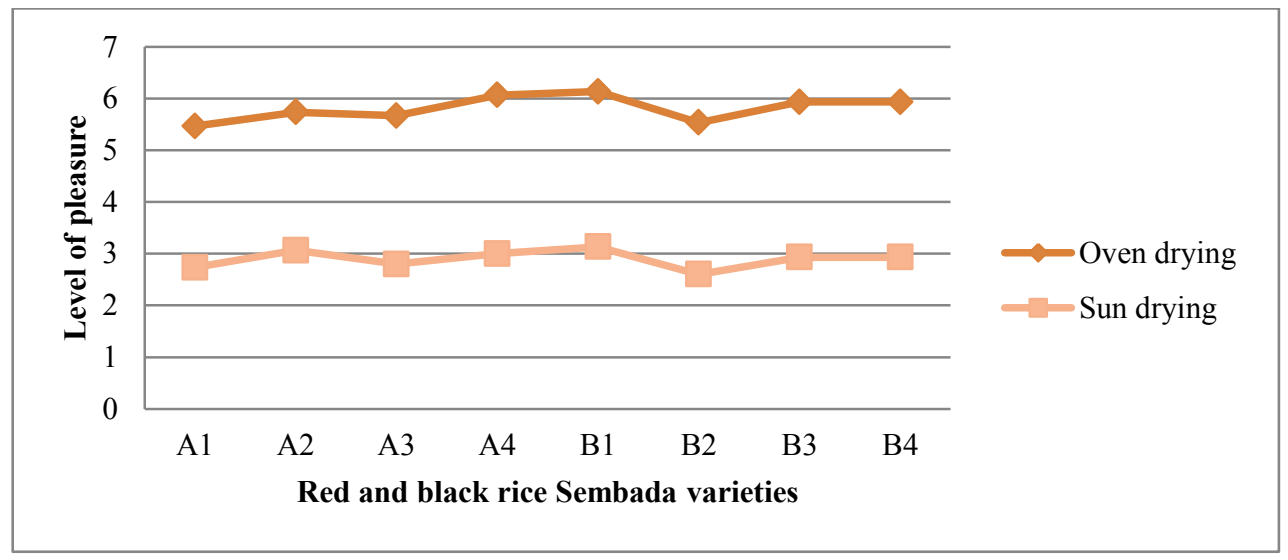

Fig. 4. Consumer preferences for the aroma of noodles

Scent can be defined as something that can be observed with the sense of smell. In the food industry, odor testing is considered important because it can quickly provide an assessment of the product about whether the product is accepted or not [9] Aroma is a determinant of product quality on whether the product is accepted or not. The appearance of aroma is caused by substances that are volatile (evaporate), slightly soluble in water and fat [10]. [11] the drying temperature greatly affects the aroma, the higher the drying temperature, the more unpleasant the aroma will be, so that consumers do not like it, but based on the results of organoleptic tests, it shows that the type and concentration of rice and the method of drying have no significant effect. This statement is not an observation because at the time of observation the aroma of black rice is very strong and has a distinctive aroma. This is because the panelists who carried out the organoleptic test were not trained enough, causing different results.

\subsection{Taste}

Taste is an important factor in determining the acceptability of a food ingredient. This is because taste involves more of the taste buds [12]. The taste of a product is an indispensable parameter. Basically, humans want food that tastes good in addition to fulfilling the need for fullness and health. In the results of the data above, it was found that the type and concentration of rice and the drying method had no significant effect on the 
noodles. This is not the results of observations, in fact, the panelists prefer brown rice noodle products with oven drying treatment with a ratio of rice flour and wheat flour 1: 1 where 100 grams of rice flour and 100 grams of wheat flour are used, this is due to the use of flour. The rice used is high enough to produce a distinctive taste of rice noodles and also the wheat flour used uses high protein flour so that when heating the protein is denatured. The heating process causes the protein in food to change or denature and form other compounds that can affect the taste and aroma of food. The drying temperature affects the taste, the higher the temperature, the less preferred the taste by consumers [11] This difference is caused by panelists who are not trained in identifying differences in taste

Table 3. The results of the ANOVA test of consumer preferences for the taste of noodles

\begin{tabular}{|c|c|c|c|c|c|c|}
\hline \multirow{2}{*}{$\mathrm{Sk}$} & $\mathrm{db}$ & \multirow{2}{*}{$\mathrm{Jk}$} & \multirow{2}{*}{$\mathrm{Kt}$} & \multirow{2}{*}{$\mathrm{F}$ Count } & \multicolumn{2}{|c|}{$\mathrm{F}$ Table } \\
\cline { 6 - 7 } & & & & & $5 \%$ & $1 \%$ \\
\hline Samples & 15 & 7.53 & 0.50 & 0.47 & 1.71 & 2.13 \\
\hline Panelists & 14 & 67.48 & 4.82 & & & \\
\hline Error & 210 & 221.59 & 1.06 & & & \\
\hline Total & 239 & 296.59 & & & & \\
\hline
\end{tabular}

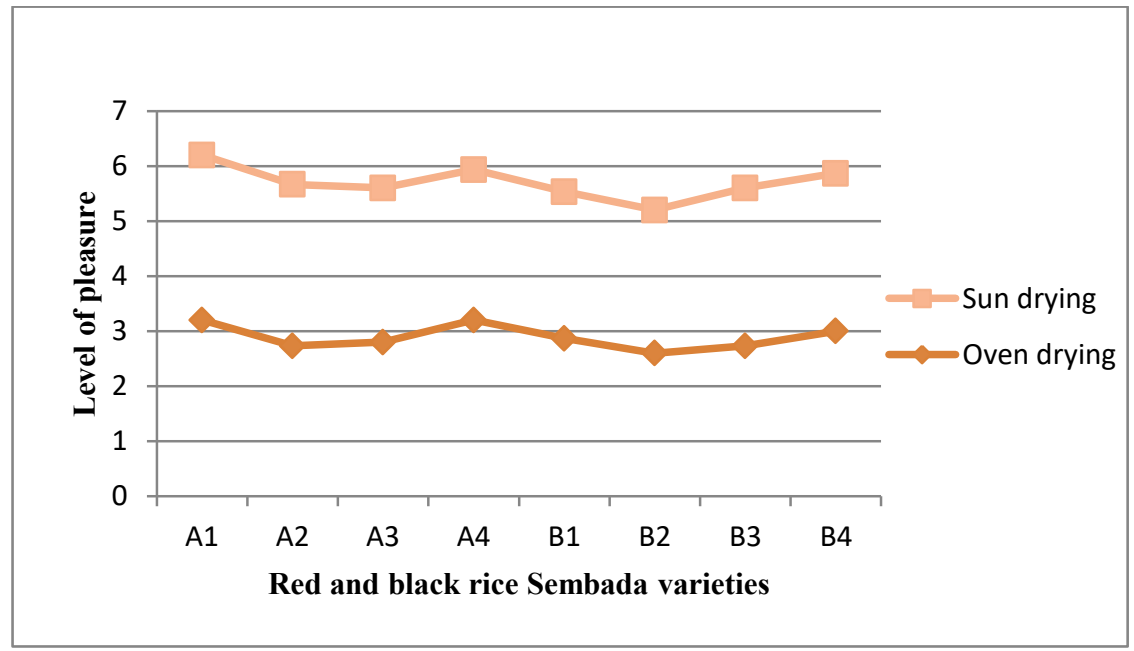

Fig. 5. Consumer preferences for noodle taste

\subsection{Texture}

The breaking power of the noodles is influenced by the gluten content in the ingredients, the proportion of amylose and amylopectin, and the dough process, apart from these factors the elasticity is influenced by the composition of the dough [13] .In the results of the data above, the results of the type and concentration of rice and the drying method have no significant effect on the noodles. This is not by the observations, in fact, the panelists prefer brown rice noodle products with oven drying treatment with a ratio of rice flour and wheat flour 1: 1, where 100 grams of rice flour are used and 100 grams of wheat flour. The chewiness of the noodles is influenced by the amylopectin content in the red and black rice flour which is substituted. The amylopectin content is high enough and the strong stickiness has the potential to form chewiness so that it can be used as a rationale as a substitute for flour in manufacturing. noodles. The flour used in the manufacture of these noodles uses high protein wheat flour and there is the addition of eggs that contain protein as well [14] 
The addition of eggs in the manufacture of dry noodles as a stabilizer between starch molecules to produce dry noodles with a good texture [15]. This difference was caused by the panelists who were not trained in identifying differences.

Table 4. The results of the ANOVA test of consumer preferences on the texture/elasticity of noodles

\begin{tabular}{|c|c|c|c|c|c|c|}
\hline \multirow{2}{*}{$\mathrm{Sk}$} & \multirow{2}{*}{$\mathrm{db}$} & \multirow{2}{*}{$\mathrm{Jk}$} & \multirow{2}{*}{$\mathrm{Kt}$} & \multirow{2}{*}{$\mathrm{F}$ Count } & \multicolumn{2}{|c|}{$\mathrm{F}$ table } \\
\cline { 6 - 7 } & & & & & $5 \%$ & $1 \%$ \\
\hline Sampels & 15 & 12.06 & 0.80 & 0.91 & 1.71 & 2.13 \\
\hline Panelists & 14 & 74.43 & 5.32 & & & \\
\hline Error & 210 & 185.44 & 0.88 & & & \\
\hline Total & 239 & 271.93 & & & & \\
\hline
\end{tabular}

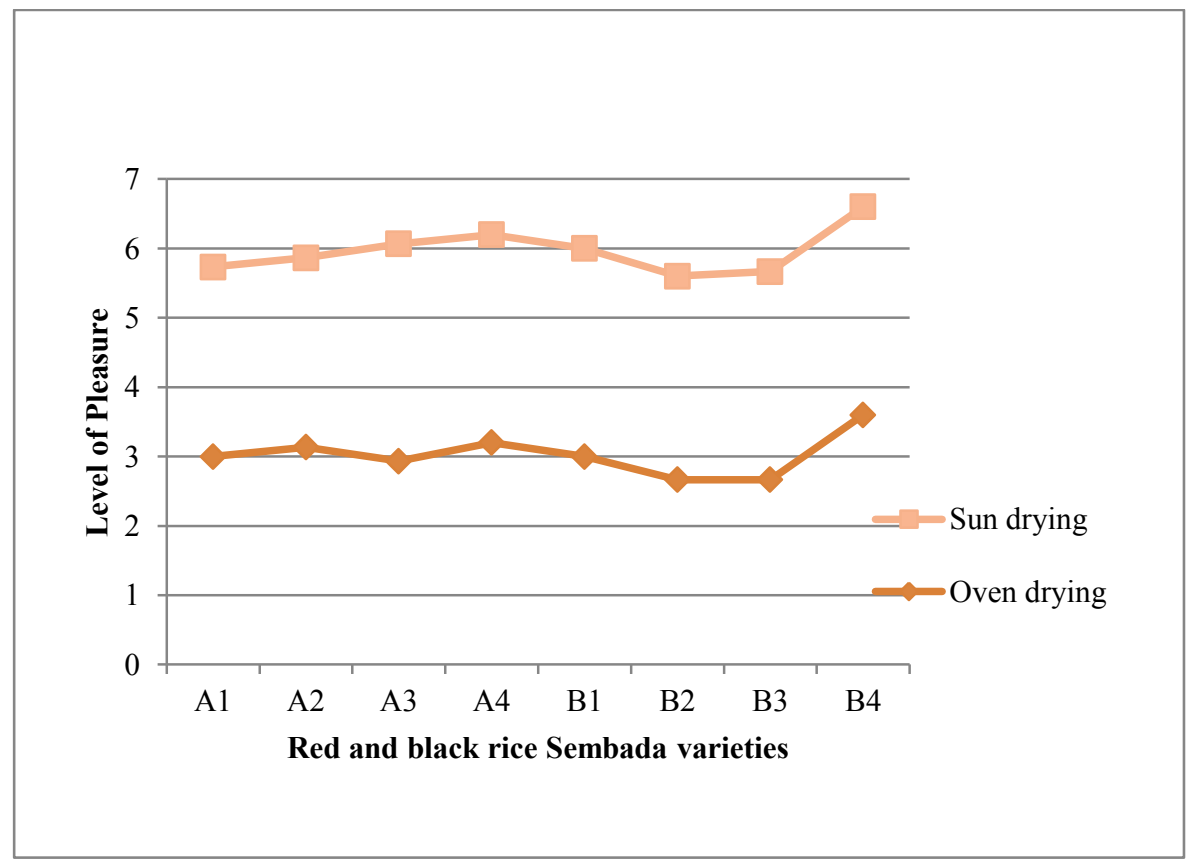

Fig. 6. Consumer preferences on the texture/elasticity of noodles

\section{Conclusion}

Based on the results of the study, it can be concluded that the results of the organoleptic test of noodles with the substitution of brown rice and black rice had a significant effect on the color, aroma, taste, and elasticity of noodle products statistically. Drying has a significant effect on color assessment. But it has no effect on the assessment of taste, aroma, and elasticity. Panelists prefer A4 noodles (brown rice flour noodles with $100 \%$ concentration) with cabinet dryer treatment. The resulting color is more attractive, the distinctive aroma and taste of the rice flour used and the resulting elasticity is also highly favored by the panelists. 


\section{References}

1. A. N. Hardoko, Saputra T.F, J. Perikan. Dan Kelaut. 18, (2013).

2. M. V Hernawan E, J. Kesehat. Bakti Tunas Husada 15, 79 (2016).

3. H. S. Azis A, Izzati M, J. Biol. 4, (2015).

4. M. of Health, Indonesian Food Composition Table in 2017 (Jakarta, 2018).

5. P. D. Forsalina F, Nocianitri KA, J. Ilmu Dan Teknol. Pangan 5, (2016).

6. T. J. Mutters, Trans. ASABE 49, 435 (2006).

7. R. N. Sunarti TC, Pascapanen 1, 29 (2004).

8. S. D. Billina A, Waluyo S, Jur Nal Tekn Ik Per Tan Ian Lampun G 4, 109 (2014).

9. D. Kartika, hastuti, Supartono dalam C. Maliluan, Y.B. Pramono, Guidelines for Sensory Testing of Food Ingredients in Physical and Sensory Characteristics of Chicken Nuggets With Utilization Rice Brain to Substitute Wheat Flour (2013).

10. I. K. Marliyati, Anna in Salmin N, Hermanto, Food Sci. Technol. 2, 958 (2017).

11. H. Purwaningsih, Ulfah M, Sangari, Nuryanti, in 3rd Int. Conf. Food Agric. IOP Conf. Ser. Earth Environ. Sci. 672012049 (2021).

12. M. Winarno in Utami A P, Wahyuni S, Food Sci. Technol. 1, 79 (2016).

13. R. J. Fitriani, Substitution Of Sorgum Flour For Elongation And Acceptance Of Wet Noodles With Proportional Water Volume, Muhammadiyah Surakarta University, 2016.

14. P. Handajani, in 6th Int. Conf. Sustain. Agric. Food Energy (2019).

15. W. Mulyadi FA, wijana S, ika, in Semin. Nas. BKS PTN Barat (2014). 